\title{
Spindle cell lipoma of peri-parotid soft tissues. Report of a case and histogenetic considerations
}

\author{
Francesca Flavia Amore' ${ }^{1}$, Giuseppe Musumeci ${ }^{2 *}$, Paola Castrogiovanni ${ }^{2}$, Francesca Romana Longo ${ }^{1}$ and Gaetano Magro ${ }^{1}$
}

*Correspondence: g.musumeci@unict.it

CrossMark

$\leftarrow$ Click for updates

\begin{abstract}
'Department of Medical and Surgical Sciences and Advanced Technologies, G.F. Ingrassia, Azienda Ospedaliero-Universitaria "Policlinico-Vittorio Emanuele", Anatomic Pathology Section, University of Catania, Catania, Italy.

${ }^{2}$ Department of Biomedical Sciences and Biotechnologies, Human Anatomy and Histology Section, School of Medicine, University of Catania, Catania, Italy.
\end{abstract}

\begin{abstract}
Spindle cell lipoma (SCL) is a rare benign tumor which occurs most commonly in the posterior neck, shoulder and back. We report a rare case of SCL arising in peri-parotid soft tissues in a 66 year-old man. This is an unusual site for such a relatively rare lesion. The histological examination of the lesion showed the typical morphological features of SCL. Only four cases of SCL of the parotid region have been reported to date. Our case emphasizes the possibility that SCL may occur in the peri-parotid soft tissue and awareness of this possibility is crucial for pathologists to avoid confusion with others primary tumors of the parotid gland in which mature adipose tissue may be a metaplastic tumor component.
\end{abstract}

Keywords: Spindle cell lipoma (SCL), soft tissue mass, parotid gland, histology, immunohistochemistry

\section{Introduction}

Spindle cell lipoma (SCL), first described by Enzinger and Harvey in 1975, is a benign soft tissue tumor tipically occurs in the posterior neck and upper trunk (back and shoulder), with a male predominance [1]. Less frequently $\mathrm{SCL}$ may involve the face, forehead, scalp, buccal-perioral area and upper arm, and only rarely it may arise in unexpected sites, including oral cavity [2,3], larynx [4], tongue [5] and lower extremities [1]. To the best of our knowledge, only four cases of $\mathrm{SCL}$ of the parotid region have been reported so far: three cases were located in the peri-parotid soft tissues [6-8] and only one case within the parotid parenchyma [9]. Clinically, SCL presents as an asymptomatic, often long-standing, oval or discoid superficial mass; grossly, unlike classic lipoma, it has a yellowish to grayish-white colour, depending on the relative extension of the fatty and spindle cell components; histologically, it is composed of two main components, mature fat and bland-looking spindle cells, which may be present in varying proportions.

We herein report a rare case of $\mathrm{SCL}$ arising as a nodular mass in right peri-parotid soft tissues of a 66 year-old man. This is an unusual site for this benign neoplasm, with only four cases previously reported [6-9].

\section{Materials and methods}

The surgical specimen was submitted for histological examination in neutral-buffered $10 \%$ formalin, dehydrated using standard techniques, embedded in paraffin, cut to $5 \mu \mathrm{m}$, and stained with hematoxylin and eosin as previously described [10-12]. Immunohistochemical analyses were performed using the standard streptavidin-biotin labeling technique (LSAB kit-Dako, Glostrup, Denmark) as previously described [10-12]. The following antibodies were tested: CD34, CD10 and S-100 protein (all from DakoCytomation, Glostrup, Denmark). Negative controls for the staining were slides stained with omission of the primary antibody.

\section{Case presentation}

A 66-year-old man presented to the Otolaryngology-Head and Neck Surgery Clinic at the University of Catania with a short history of a right-sided, painless, cheek/parotid mass. Physical examination revealed a $3.5 \mathrm{~cm}$ soft mass, most consistent with a fatty lesion. Ultrasonography examination showed a wellcircumscribed, diffuse hyperechoic mass with multiple linear or band-shaped hypoechoic areas. The neck showed no other masses or lymphadenopathy. Clinical diagnostic considerations 
included a peri-parotid soft tissue lesionversus a primary tumor of the parotid gland. The mass was surgically excised with a thin rim of surrounding parotid tissue. After three months of clinical follow-up, no local recurrence was observed. Grossly, a well-circumscribed and capsulated lipomatous mass was seen (Figure 1A). The cut section revealed a lipomatous lesion, soft in consistency and yellowish in colour. Histological examination (Haematoxylin and Eosin staining) showed a lipomatous tumor surrounded by a relatively thick fibrous capsule, with a peripheral, thin rim of parotid gland parenchyma (Figure 1B). Tumor was mainly composed of mature adipocytes (Figure 2A) with scattered fibro-myxoid areas in which were



Figure 1. (A). Gross appearance of tumor, showing a lipomatous nodule with a thin rim of parotid gland (haematoxylin and eosin staining; original magnification $\mathrm{x} 40$ ).

(B). Histological low magnification showing an encapsulated lipomatous tumor with a peripheral rim of parotid gland (haematoxylin and eosin staining; original magnification $\mathrm{x} 40$ ).

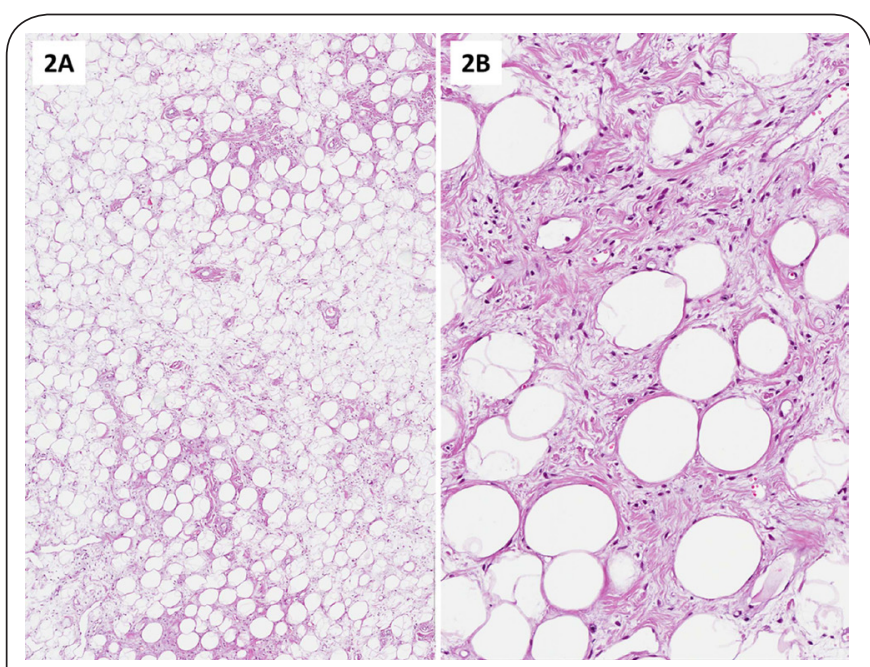

Figure 2. (A). Higher magnification of the tumor showing uniform, mature adipocytes with interspersed fibrotic areas (haematoxylin and eosin staining; original magnification x80). (B). Some tumor areas were composed of bland-looking short spindle cells with interspersed ropey collagen fibers (haematoxylin and eosin staining; original magnification x200). set bland-looking, short spindle-shaped cells intermingling with ropey collagen fibers (Figure 2B). Mast cells were also frequently encountered. Lipoblasts, nuclear pleomorphism or necroses were absent. Immunohistochemical analyses as expected, the spindle cells were stained with CD34 (Figure 3) and CD10, while mature adipocytes were decorated by S-100 protein (data not shown).



\section{Discussion}

We herein report a rare case of $\mathrm{SCL}$ arising from soft tissues adjacent to parotid gland. Our case emphasizes the possibility that $\mathrm{SCL}$ may rarely occur in the peri-parotid soft tissues, raising pre-operative differential diagnostic problems with a primary parotid gland tumor. Histological examination is mandatory in achieving the correct diagnosis. In this regard, it is crucial to establish if tumor is located outside of the parotid gland, or if it arises within it. Infact, the intra-gland tumor location poses diagnostic problems with an epithelial 
tumor exhibiting extensive lipomatous metaplasia, such as lipomatous pleomorphic adenoma or lipoadenoma [13]. In our case, the lipomatous tumor, with the typical morphological and immunohistochemical features of $\mathrm{SCL}$, was well separated from the surrounding normal parotid parenchyma by a thick fibrous capsule, and it was considered as primarily arising from the peri-parotid gland soft tissues. Accordingly, both lipomatous pleomorphic adenoma or lipoadenoma were easily ruled out on the basis of the tumor site and absence of

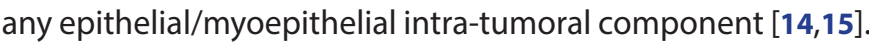
Among lipomatous tumors, a differential diagnosis was made with conventional lipoma, lipoma-like well-differentiated liposarcoma, and spindle cell liposarcoma. The former is composed exclusively of mature adipocytes, while spindle cell component and ropey collagen fibers are usually lacking [13] Unlike our case, well-differentiated lipoma-like liposarcoma contains adipocytes with hyperchromatic and atypical nuclei, and atypical stromal cells in the fibrous septa, intersecting the adipocytic component [16]. Spindle cell liposarcoma, a distinctive clinico-pathological entity occurring in soft tissues [13], is easily distinguishable from SCL for the presence, even if only focally, of lipoblasts with cytological features which closely resemble the differentiation of human embryonic fat $[17,18]$.

\section{Conclusion}

The case herein presented is rare in that it confirms that $\mathrm{SCL}$ may occur in an unusual site, namely peri-parotid soft tissues. Awareness by pathologist of this possibility is crucial to avoid confusion with other benign or malignant tumors of the parotid gland, assuring correct treatment and prognostic information.

\section{Competing interests}

The authors declare that they have no competing interests.

Authors' contributions

\begin{tabular}{|l|c|c|c|c|c|}
\hline Authors' contributions & FFA & GM & PC & FRL & GM \\
\hline Research concept and design & $\checkmark$ & $\checkmark$ & -- & -- & $\checkmark$ \\
\hline Collection and/or assembly of data & $\checkmark$ & $\checkmark$ & $\checkmark$ & $\checkmark$ & $\checkmark$ \\
\hline Data analysis and interpretation & $\checkmark$ & $\checkmark$ & $\checkmark$ & $\checkmark$ & $\checkmark$ \\
\hline Writing the article & $\checkmark$ & $\checkmark$ & -- & -- & $\checkmark$ \\
\hline Critical revision of the article & $\checkmark$ & $\checkmark$ & $\checkmark$ & $\checkmark$ & $\checkmark$ \\
\hline Final approval of article & -- & -- & -- & -- & -- \\
\hline Statistical analysis & -- & -- & -- & -- & -- \\
\hline
\end{tabular}

\section{Acknowledgement}

This study was supported by grants provided by the Department of Medical and Surgical Sciences and Advanced Technologies, G.F. Ingrassia, Azienda OspedalieroUniversitaria "Policlinico-Vittorio Emanuele", Anatomic Pathology Section, University of Catania, Catania, Italy.

Publication history

Editor: Lingyan Wang, Oregon Health \& Science University, Portland. Received: 14-Jan-2015 Final Revised: 16-Mar-2015

Accepted: 02-Apr-2015 Published: 06-Apr-2015

\section{References}

1. Finn LS, Mentzel T, Goodland JR, Smith MA and Fletcher CDM. Ancient hematoma: a unifying concept for a post-traumatic lesion mimicking an aggressive soft tissue neoplasm. Mod Pathol. 1998; 11:799-800. | PubMed

2. Lombardi T and Odell EW. Spindle cell lipoma of the oral cavity: report of a case. J Oral Pathol Med. 1994; 23:237-9. I Article I PubMed

3. Levy FE and Goding GS, Jr. Spindle-cell lipoma: an unusual oral presentation. Otolaryngol Head Neck Surg. 1989; 101:601-3. | Article | PubMed

4. Nonaka S, Enomoto K, Kawabori S, Unno T and Muraoka S. Spindle cell lipoma within the larynx: a case report with correlated light and electron microscopy. ORL J Otorhinolaryngol Relat Spec. 1993; 55:147-9. | Article | PubMed

5. Dutt SN, East DM, Saleem Y and Jones EL. Spindle-cell variant of intralingual lipoma--report of a case with literature review. J Laryngol Otol. 1999; 113:587-9. | Article | PubMed

6. Fasig JH, Robinson RA, McCulloch TM, Fletcher MS and Miller CK. Spindle cell lipoma of the parotid: fine-needle aspiration and histologic findings. Arch Pathol Lab Med. 2001; 125:820-1. I Article I PubMed

7. Rosenthal LS, Garzon S, Setty S and Yao M. Left-sided facial mass. Spindle cell lipoma of the parotid gland. Arch Pathol Lab Med. 2006; 130:875-6. | Article I PubMed

8. Agarwal S, Nangia A, Jyotsna PL and Pujani M. Spindle cell lipoma masquerading as lipomatous pleomorphic adenoma: A diagnostic dilemma on fine needle aspiration cytology. J Cytol. 2013; 30:55-7. I Article | PubMed Abstract | PubMed Full Text

9. D’Antonio A, Baldi C, Memoli D, Caleo A, Rosamilio R and Zeppa P. Fine needle aspiration biopsy of intraparotid spindle cell lipoma: a case report. Diagn Cytopathol. 2013; 41:171-3. | Article | PubMed

10. Longo F, Musumeci G, Ferrara G, Trombatore C and Magro G. Retroperitoneal cellular schwannoma(CS): a potential pitfall of malignancy. report of acase and review of the literature. $J$ Histol Histopathol. 2014; 1:14. I Article

11. Longo F, Musumeci G, Amore F, Motta F and Magro G. Rhabdomyomatous mesenchymal hamartoma(RMH) of the anal region: an unusual location forsuch a rare lesion. J Histol Histopathol. 2014; 1:8. I Article

12. Musumeci G, Imbesi R, Magro G, Parenti R, Szychlinska MA, Scuderi $\mathrm{R}$, Castorina $\mathrm{S}$ and Castrogiovanni $\mathrm{P}$. $\mathrm{N}$-cadherin has a protective role in stable human atherosclerotic plaques: a morphological and immunohistochemical study. J Histol Histopathol. 2014; 1:4. | Article

13. Weiss SW and Goldblum JR . "Enzinger and Weiss's Soft Tissue Tumors"5th edition. Mosby, Inc. An affiliate of Elsevier. 2008.

14. Seifert G, Donath K and Schafer R. Lipomatous pleomorphic adenoma of the parotid gland. Classification of lipomatous tissue in salivary glands. Pathol Res Pract. 1999; 195:247-52. | Article | PubMed

15. Haskell HD, Butt KM and Woo SB. Pleomorphic adenoma with extensive lipometaplasia: report of three cases. Am J Surg Pathol. 2005; 29:138993. | Article | PubMed

16. Vecchio G, Amico P, Caltabiano R, Colella G, Lanzafame S and Magro G. Spindle cell/pleomorphic lipoma of the oral cavity. J Craniofac Surg. 2009; 20:1992-4. | Article | PubMed

17. Dei Tos AP, Mentzel T, Newman PL and Fletcher CD. Spindle cell liposarcoma, a hitherto unrecognized variant of liposarcoma. Analysis of six cases. Am J Surg Pathol. 1994; 18:913-21. I Article I PubMed

18. Deyrup AT, Chibon F, Guillou L, Lagarde P, Coindre JM and Weiss SW. Fibrosarcoma-like lipomatous neoplasm: a reappraisal of so-called spindle cell liposarcoma defining a unique lipomatous tumor unrelated to other liposarcomas. Am J Surg Pathol. 2013; 37:1373-8. | Article | PubMed

Citation:

Amore FF, Musumeci G, Castrogiovanni P, Longo FR and Magro G. Spindle cell lipoma of peri-parotid soft tissues. Report of a case and histogenetic considerations. J Histol Histopathol. 2015; 2:7. http://dx.doi.org/10.7243/2055-091X-2-7 